\title{
Essential Elements of the Franchise Contract and the Advantages of Implementation in the Albanian Market
}

\author{
Prof Asoc Dr Julejda Aliaj (Gërxhi)
}

\author{
Department of Law, \\ Faculty of Political and Juridical Sciences, \\ University "Aleksander Moisiu" Durrës
}

Msc. Enkelejda Haxhiraj

Doi: 10.2478/ajis-2018-0062

\begin{abstract}
The franchise contract was a type of contract used frequently in trading during the Middle Ages. However, for almost a century, this contract is being used by business law entities, which want to enter the business and have a bigger profit. Regardless of the technical-legislative elements or special features of the parties' juridical-civil relationship, franchising contract is a form of business. It is considered to be one of the easiest contracts in civilian use by different persons, not only about the innovations provided from the commercial aspect, but also as a reflection of modernity and the progress in trading. The franchise contract is a concept envisioned by Albanian legislation, but practically it has been implemented rarely and not in line with current domestic market requirements. In these conditions, its application has provided disputes between the signatory subjects. For this reason, the essence of this work will be not only the legal-civilian understanding of the franchise contract, but also the way this contract is implemented in Albania. The study will be based on the use of the analytical method of advantages that the franchise contract application aims to produce by referring to its legal-civilian analysis. We also aim to use the comparative method of implementation of this contract in Western countries. This study will present the advantages that the franchise contract produces $b$ from the civil law aspect, in view of its practical implementation by the contracting parties. This study aims to move forward in a more in-depth analysis of the franchise contract in the Albanian reality and the shortcomings that this contract presents, in relation to the most developed countries. Also, franchising does not operates only through a simple, typical contract, but transforms and is transformed in a variety of ways , which should be analyzed so that to point out and reveal the product of franchising and the benefits it brings to the contracting parties.
\end{abstract}

Keywords: franchising contract; legislation; contracting parties; rights and liabilities; advantage

\section{Introduction}

Involvement in economic relations with the purpose of increasing profits is not something easy and risk-free. However, the reality offers a number of opportunities to anyone wishing to trade or make economic profits, especially to those aspiring to follow a path that leads to large profits in the economic aspect.

A sales agreement may be entered into to purchase or sell goods; a supply agreement may be entered into for long-term supplies, and in this way another issue related to the eventual business is solved. If one wishes to obtain a license for a particular good, on which a number of industrial or intellectual rights exist, of course this can be done by entering into an agreement with the person holding the concerned good. So, it is clear that for any aspired activity there is a legal or 
contractual approach through which to make economic profit. However, there are cases when we need only one action to comprise any of the abovementioned approaches for a guaranteed economic success.

Such an action is the Franchise agreement. Referring to the etymology of this word [the root "franc" from the Middle Ages means privilege] we see that his approach provides something more special in comparison with the standard methods of economic interaction in our modern society. The Franchise agreement, once employed by the medieval society, for over a century is being employed by legal entities who wish to do business and make profits. More than a contract to analyze from the technical-legislative view point in terms of the characteristics and updates it provides to the legal-civil relations between parties, this contract is generally a successful way to do business. If we were to analyze the reasons why this contract is employed (only recently in Albania), then it would be worth prioritize the advantages it offers. Different enterprises face multiple risks that might not only harm their business but also affect negatively similar initiatives of individuals involved in such enterprises, while the Franchise agreement suffers the phenomenon of legal uncertainty in a volatile economic reality.

This contract is characterized by its unique relation "profit-profit" in comparison with any other contract, due to its distinguished characteristics.

The relation "profit-profit" means a situation in which, theoretically, both parties win not only in financial terms but also in terms of rights and dues assumed to each-other.

This situation is advantageous to anyone wishing to start a business or enterprise; however, a volatile economic reality cannot give guarantees to the contract parties, especially in terms of economic-financial profit, given that the risks have always to be considered in every initiative taken, as starting a business means taking risks.

Referring to the Albanian legislation, the Franchise agreement is something new. It shows a modern aspect of the civil code, especially that of a country which only 28 years ago was suffering the dictatorial system. However, when modernity is inconsistent with the current requirements of the economy of a given country, it often lacks something and needs time to adapt, and the legal provisions are the one to precede the requirements or innovative initiatives of that country.

This work is aimed at taking a modest step towards a deeper analysis of the Franchise agreement in Albania and the shortcomings it presents in comparison with more developed countries that have already prioritized its advantages.

Franchise is not just a typical simple contract but it transforms into a variety of ways, for which there is a need to analyze on one side the Franchise product and the rights and dues on the parties thereof on the other.

The Franchise agreement minimally involves two parties, which may be natural or legal entities, namely the franchiser, who gives its product or brand in Franchise to another entity (the franchisee) selected by the same franchiser to operate on its behalf.

This contract will be analyzed by also suggesting the need for necessary amendments to the civil code in force (referring to the best international case-law in this aspect), so as this particularly efficient contract may be adapted to the domestic economic reality and be employed by more individuals wishing to start their own business. In this way the profit will extend not only to them as individuals but also to the domestic economy.

\section{The Meaning of the Franchise Agreement and Its Types}

It has always been difficult to find a unified definition of the Franchise concept, as there are a number of definitions that law or doctrine provide for such contract. Moreover, the early analysis of its elements showed some doctrinal ambiguity in terms of the similarity of Franchise to other contracts, especially for periods earlier than the development of case-law. However, from the etymological viewpoint, the word "franchise" has an Anglo-French origin, where the root of the word "franc" means "free". Under another interpretation, the root "franchise" means "privilege" or "grant", and it originates from the Middle Age. This word was used to describe the acknowledgment of a privilege, and the villages meant to be used as reserved privileges for the Lords were called "franc towns" (http://www.pme.gouv.fr/informations/guidecom/telechar/franchise/franchise.html) 
Essentially, Franchise may be considered as a marketing system for products or services. It is a contract between two parties, the franchiser and the franchisee, where the franchiser allows the franchisee to trade a given product or service under its brand, trademark or symbol in exchange of an initial fee or a trust fee, or both fees. Article 1056 of the civil code provides no clear definition on the Franchise agreement, but defines it as a contract including a number of constant obligations for which independent enterprises are liable to each-other to jointly encourage and develop trade and carry out services in compliance with specific obligations.

So, this provision just highlights that in Franchise there are a number of constant obligations between the parties aimed at encouraging and developing trade and service supply. The definition comprises a list of rights and obligations binding upon the parties under Franchise, but it fails to give a specific definition of the Franchise agreement, by focusing on its content.

Referring to the above provision, the purpose of the Franchise agreement is to make available for the franchisee a standardized set of non-material rights, models, designs, profit, trade, organization ideas and other appropriate know-how for the Franchiser to develop trade. So, in this contract, it is the franchisee to make the investment and it should not be considered as an employee of the franchiser, given that the franchisee runs its own business and invests in this business.

A characteristic of Franchise is the transfer of "know-how" to the franchisee. It is obtained as a sort of obligation of the franchiser to train the franchisee on how to trade a product or supply a service. Essentially and in terms of distribution, the franchiser is a supplier who consents the operator or franchisee in this case to use the supplier's trademark or symbol and distribute the supplier's goods. In exchange, the operator pays a certain amount to the supplier. (David.Gurnick. "Distribution Law of the United States", U.S.:Juris Publishing, 2011, pg. 35).

A more accurate definition of Franchise is provided in a judgment of the European Court of Just regarding the "Pronuptia"case: "...in a Franchise distribution system (...) an enterprise that has been identified as distributor in a given market and consequently has developed certain business methods, grants to independent traders, in exchange of a fee, the right to operate in other markets using its name and those business methods that have resulted successful (Case no. 161/84, European Court of Justice, 28 January 1986). More than a distribution method, it is a way for an enterprise to generate profits from its expertise without investing its own capital. Moreover, this system gives inexperienced traders the opportunity to apply methods, which, otherwise they could not have learned without considerable efforts, and allows them to benefit from the reputation of the franchiser's trademark".

In this judgment the European Court of Justice distinguishes three types of Franchise agreements by contributing even to the doctrine:

1. Products Franchise, in which the franchisee produces goods under the instructions of the franchiser and sells them under the brand name of the franchiser;

2. Distribution Franchise, in which the franchisee just sells certain products in a marketplace, which has the franchiser's brand name or symbol;

3. Service Franchise, in which the franchisee supplies a service under the brand, symbol and sometimes trademark of the franchiser as instructed by the latter.

In addition to such well-defined categories by the European Court of Justice, recently, due to the extension of its application and the facilities it provides to the market to extend the way to do business, other types of Franchise have been developed, such as:

a. Social Franchise, in which disabled individuals are hired to work in business dealing with simple tasks, easily affordable by this category.

b. Logistics to third parties is a form of business specialized in providing assistance to individuals wishing to transport their goods between countries. This form of business is rapidly growing due to the increasing demand of people to transport their goods, as well as to the excessive number of transport means and the affordable cost that this type of Franchise incurs.

c. Home-based Franchise is another way to do business (Issie.Lapowsky., Inc. (magazine: How to start a home-based franchise", New York: 13.05.2010). This type of Franchise is based on replicating another home-based business. It has some initial costs, but is 
considered as one of the best ways to do business for individuals wishing to enter the business world, although the numerous difficulties encountered along the road to success.

d. Events' Franchise is another type of Franchise, which intends to replicate public events in countries that are geographically different from the country of origin, but always keeping the logo and symbol of the original event, as well as its mission, concept and format. This type of Franchise deals mainly with replication of successful events.

Referring to the Franchise agreement and the variety of its uses, it's worth mentioning even its complexity, because it contains elements of other contracts, such as sales contract, supply contract, joint venture contract, licensing agreements related to industrial property rights; agreement for know-how transfer, etc. so, Franchise contains elements of the abovementioned contracts, although it is specifically regulated by international laws as well as the civil code of the Republic of Albania.

\section{Advantages and Disadvantages of Using the Franchise Agreements}

Business today are moving toward the extension of their trade activities by promoting their goods and services beyond geographical barriers, because through other trade companies they carry out the exclusive sale of products or services of a well-known producer under the same trademarks and symbols. This is rendered through the Franchise agreement.

The reason why this contract is preferred relate mainly to the experience of the franchiser and the other benefits thereof. The essence of Franchise lies in the profit-profit business situation for both parties.

The franchiser seeks to extend its business with little input or financial investment, and the franchisee is ready to spend money and do business in a way that it is not obliged to start up.

Generally, two parties are identified in Franchise, the franchiser and the franchisee, which have advantageous and disadvantageous viewpoints in terms of its use. Precisely, the Franchise agreement expands business faster than the means available for the company, and this happens simply because the number of individuals and the amount of money involved in Franchise operations are greater than when the company has to invest her sources to expand the market activity.

On the other side, there may be a loss of control over the network if the franchiser expands more than it can handle. The franchiser may also create the illusion of not having to pay so much attention or interest to daily operations or activities of its business, as it is the franchisee to do all the job (J.Gamet - Pol Francoise, "Franchise Agreements within The European Community", USA: Transnational Publishers, Inc. 1997, pg. 14).

In addition, the Franchise agreement may be viewed as a way to increase capital, with the franchiser investing less money than in opening branches of the company, because every franchisee brings its own capital to start its part of the business. So, from this perspective, we may note the reciprocity that characterizes the franchise relation between the parties, as well as the fact that this situation is profitable for both parties. It also guarantees income from payments and trust of franchisee to franchiser.

Marketing efficiency and saving costs and money are advantages of franchise, and more important, financial risks are minimal.

When expanding business in a geographical area through franchise, franchisees from the new areas provide information on the market of the area where they are practicing their activity. This indicates the role of franchisees especially when they start their activity in new places. Another advantage of franchiser-franchisee relation is the research and development of facilities, which come as reports from franchisees. When franchisees interact in such issues as employment or direct business management responsibilities, the franchiser has more time to concentrate on the general aspects of company management.

Disadvantages of this type of agreement may be in terms of profits, which do not go entirely to the franchiser, given that the franchisees have also their profit share, and this would not occur if all sale points or businesses were run by the franchiser only.

Costs for running franchise businesses such as legal costs or compulsory training to 
franchisees are disadvantageous for the franchiser. In addition, making profits for both parties requires time, as most franchisees need at least one year to have profitability (Kevin B. Murphy, "The Franchise Handbook: A Complete Guide to all Aspects of Buying, Selling or Investing in a Franchise" USA: Atlanta Publishing Group, Inc., 2006, pg.185).

In franchise, the franchiser and franchisee view issues from different perspectives and may have different goals in developing their shares of business. The franchiser should bear in mid that the franchisee is not an employee but an independent operator under a franchise agreement.

The relation between the parties is somewhat a "step of trust". The franchiser should be able to trust to the franchisee and renounce a part of business development by giving such a privilege to a stranger, a franchisee.

As in every relation even in franchise disputes may exist about certain issues, especially when things fail to go as expected by one party; however, these are problems to be faced and resolved as they emerge.

Conflicts for which no settlement can be achieved may cause the franchisee to give up. In such case, the latter may start its own business by using its own experience and the business know-how gained from franchise agreement implementation, and it may transform into a direct business competitor of the franchiser (Ian Murray, "How to choose a franchise". UK: Express Newspapers, 2004, pg. 19).

In every relation parties bring their own experiences with them. In franchise, a good aspect is the fact that every franchisee has various know-how and ideas on management, marketing, new motivation, etc. However, the differences they bring may at the same time be the reason of an eventual conflict, as either party believes has more information, know-how or possibilities than the other, and this can put the business at risk.

Generally, in franchise agreement, disadvantages originate from the relation between the franchiser and the franchisee. If the relation is correct, the business will be efficient. Relation between the parties in franchise is like legal cohabitation, when it comes to choosing the proper partner to "live" together. In this kind of agreement, if there is trust and understanding between the parties "the commercial cohabitation" will work perfectly and everybody will go toward profit and success. In franchise, independently of how much perfect is the conception, if the franchiser involves in permanent disputes with the franchisee, there will be no success in implementing the contract terms.

\section{Franchise Agreement under the Albanian Laws and Its Elements}

Under the Albanian laws, franchise is an agreement regulated by the provisions of the civil code (Law no. 7850, date 29.07.1994 "Civil Code of the Republic of Albania" amended, articles 10561064).

The franchise agreement is new to the Albanian reality and there is a huge lack of case-law in terms of the application of the relevant provisions of the civil code. Article 1056 of the civil code provides a definition of the franchise agreement, as: "a contract including a number of constant obligations for which independent enterprises are liable to each-other to jointly encourage and develop trade and carry out services in compliance with specific obligations".(Law no.7850, dated 29.07.1994 "Civil Code of the Republic of Albania" amended, article 1056). So, the Albanian legislation emphasizes the mutual relation that characterizes the franchise agreement.

Such relation, under the Albanian legislation, is characterized by a number of constant obligations between the franchiser and the franchisee, not only to each other but also to the business they are respectively running, or to the application of the mutual obligations. It is important to highlight the fact that obligations here are not only material one, as the focus is on either the franchiser or the franchisee to jointly encourage and develop the business. This means that there will be moral support and assistance in case of difficulties incurred by either party, with the joint aim of encouraging a fruitful future for the business. Therefore, this is an agreement which easily varies from being a contract with material obligations to also being a contract with non-material obligations, which means that its aim is to help both parties extend and consolidate the business, rather than to create obligations. We can identify the necessary elements of a franchise agreement 
in the provisions of the civil code that deserve a detailed analysis, so as to understand the shortcomings observed in relation to the practical implementation of this agreement in Albania. Precisely:

\subsection{Negotiations}

Article 1058 of the civil code provides, "while negotiating on the conclusion of the contract, the parties should disclose to each other the state of the commercial affairs related to the franchise agreement and specifically the agenda of the franchise obligations, and inform each other under the principles of good faith. They must not disclose classified information even if the contract is not concluded (Law no. 7850, dated 29.07.1994 "Civil Code of the Republic of Albania" amended, article 1058/1).

So, it is clear that this is not a normal situation of negotiating the contract terms (considering that there is room in the franchise agreement to negotiate terms), as, in general, this agreement is supplied by the franchiser with specified terms, especially when the franchiser is a powerful one and imposes strict terms. Despite this fact, one can easily note the great role of good faith and discretion that should characterize this type of agreement. Indeed, the role of discretion is so important that the parties, even if the contract is not concluded, must not disclose classified information provided during conversations or negotiation on the conclusion of the contract. The party failing to follow such obligation is due to indemnification. The prescription term for such obligation is three years from the date of termination of negotiations.

The lawmaker has considered the case of the eventual breach of good faith and fair competition. It may happen that one party enters into negotiation just to get the necessary information and start its own business based on the know-how of the franchiser. This situation has been appropriately set forth by penalizing the party showing lack of honesty or negotiating in bad faith. This party must compensate the franchiser, and the franchiser is entitled to such right up to three years following the termination of the negotiations, once the latter becomes aware of the breach within such term. The right is prescribed after the term of three years (Law no. 7850, dated 29.07.1994 "Civil Code of the Republic of Albania" amended, article 1058/2).

Referring to this legal provision, the prescription term is preclusive and relates to the termination of the negotiations. But it is not always the franchisee to breach the good fait, although it is taken for granted in most cases, as the franchiser is the one to share the business secrets with the franchisee. This is specifically understood even by the third paragraph of article 1058 of the Civil Code of the Republic of Albania, providing, "The party attending the negotiations may claim payment of any cost incurred under the legal faith of contract conclusion, which was not achieved due to the intentional behavior of the other party". So, in this case, should the franchiser terminate the negotiation due to his intentional behavior, the franchisee, minimally is entitled to claim payment of costs incurred, as long as the same follows the provision of non-disclosure of classified information given during the negotiations for three years following the termination of the negotiations.

Another element of franchise agreement conclusion is the adhesion contract. The franchise agreement is usually characterized by lack of negotiation, as one party must impose in advance any and all contract terms. It is precisely this type of agreement that take the notion of an adhesion contract (Ms. Lena Peters and Ms. Marina Schneider, "The Franchising Contract, Preliminary Study", Undroit: Rome, October 1986, pg.30).

The franchisee will generally conclude the agreement without changing the sample contract supplied by the franchiser. This happens in most cases, notwithstanding the fact that in this mutual relation that is about to be built it is the franchiser to take more risks. Therefore, the franchiser must be more protected either in terms of its business performance or in terms of determining the business performance rules. Here, the reputation of the franchisers trademark or name is at stake.

That is why the franchiser should provide that the franchisee be attentive in respecting any and all rules that the same franchiser deems reasonable for the policies applied by his network, so that the quality and standard of its goods or services be at the appropriate level. On the other hand, the franchisee is more reluctant in determining new terms, given that during the negotiations' 
phase, the franchisee should listen to the terms proposed "a priori" by the franchiser. Of course the intervention of the franchisee in amending any specific term set forth in the contract is possible; however, in theory, the franchise agreement preserves the initial framework.

\subsection{Form of the franchise agreement}

The franchise agreement has to be in written form and provide, among others, a unanimous specification of the mutual obligations binding on the parties, the duration of the contract and other essential elements thereof. The text of the agreement must contain a full description of the agenda of the franchise obligations (Law no. 7850, dated 29.07.1994 "Civil Code of the Republic of Albania" amended, article 1059).

By analyzing the relevant provisions of the civil code, it seems that franchise is a consensual agreement, the existence of which depends only on the will of the parties.

With regard to its form, our law requires that the franchise agreement is made in written, emphasizing the specification of mutual rights and dues of the parties, which means that this specific form is needed for verifiability rather than validity. It is justified by the fact that this agreement is not aimed, through its form, at building a relation, as, under the contemporary trends, the relation may be built even through concrete actions without the need to enter into a formal agreement.

However, referring to the Albanian legislation, this agreement is more aimed at setting forth some rules determined by the parties during the negotiations, which contain even classified information.

In this way, the agreement serves just for verifiability purposes, to prove in a formal way and even for marketing effects, the existence of a relation already built between the franchiser and the franchisee, where the latter has now become part of a wider business network that keeps the name or trademark and reputation of the franchiser.

Referring to this fact, we are likely to find this agreement as a standard contract, with terms specified by the franchiser. Moreover, franchise agreements are designed by the powerful franchiser, who takes advantage of the powerless franchisee as far as the legal aspects of the contract terms are concerned.

In this context, practically it is the franchiser to determine the contract terms.

It implies the fact that the franchiser is the party with a certain reputation in the market and normally, it should have the privilege to choose the franchisee, which will benefit from using the name and other advantages of the franchiser. The goal of the franchiser while choosing the franchisee and determining the contract terms, is to make sure that the client is going to receive the same quality of goods and services from the franchisee as the quality that the franchiser itself provides, and the form of this agreement is not of primary interest for the parties.

Therefore, this agreement is generally characterized by lack of negotiation, with one party imposing in advance any and all contract terms (Lena Peters and Marina Schneider, "The Franchising Contract, Preliminary Study", Unidroit, Rome, October 1986, pg.30).

\subsection{Parties of the franchise agreement}

In franchise agreement, parties are generally characterized by their specific situation of profit-profit. This is because both parties take advantage of such agreement in many aspects, whereas the obligations are insignificant in comparison with the opportunities granted by franchise.

The civil code of the Republic of Albania, literally defines two parties that enable a franchise contract to be entered into: the franchiser and the franchisee.

Article 1056 of the civil code employs the term "independent enterprise" when defining the franchise agreement (Law no. 7850, dated 29.07.1994 "Civil Code of the Republic of Albania" amended, article 1056).

So, the law requires that, they be independent enterprises, i.e. enterprises with no legal or actual ties between them, which otherwise would exist either for shareholding of one enterprise to the other, or due to existence of the actual dependency resulting from the business relation built 
between such enterprises.

Referring to the law "Traders and trade companies" there is a dependency relation between trade companies "when a trade company behaves and acts regularly under the guide and instructions of another company" (Law no. 9901, dated 14.04.2008 "Traders and trade companies" amended, article 207/1).

This kind of dependency is considered a controlling group. Another model of company grouping is the influence group, which exists in those cases when a company, based on the share of equity held by another company, or based on an agreement with that company, is entitled to appoint at least $30 \%$ of the managers, members of the board of directors or of the supervising council thereof. When the company holds at least $30 \%$ of the total votes to the general meeting, than it is considered as the mother company of the other company, whereas the other company is considered as the controlled company (Law no. 9901, dated 14.04.2008 "Traders and trade companies" amended, article 207/2).

The element of "independence" is a premise to make the franchise agreement, as, otherwise, if companies, enterprises or entrepreneurs depended on each-other, than the entity would be the same.

On the other hand, if a franchiser decided to establish a "daughter company" or a branch to serve as franchiser in a franchise agreement with third parties, it could not be considered a franchise agreement, although of interest in covering the relation between mother and daughter companies or branches thereof.

The reasons for such a choice may be different, for example the tax facilities this company may have, but it can in no way constitute a franchise agreement for failure to fulfill the independence requirement.

By literally interpreting the provision of article 1056 of the civil code, we see that the focus is on private profit-making legal entities as a party in the franchise agreement; however, even natural entities may be a party in the franchise agreement as entrepreneurs in the business area.

Indeed, the term "enterprise" means: 1. "undertake", "undertaken"; large activity or work performed in a given area; 2. essential unit for managing production, trade, services, etc. (Academy of Science of Albania, Institute of Language and Literature, "Vocabulary of Modern Albanian", Tirana: Toena, 2002, pg. 833).

So, from this linguistic perspective, not only legal but also natural entities can develop an enterprise.

Therefore, the franchise agreement intends to facilitate doing business by everyone, and recently the number of natural entities performing activities through franchising is increasing.

\subsection{Content of franchise agreement}

The characteristic of the franchise agreement is the fact hat the support provided therein is not unilateral (Lena Peters and Marina Schneider, "The Franchising Contract, Preliminary Study", Unidroit: Rome, October 1986, pg.32). The franchiser cannot succeed if the franchisee fails in his implementation of the agreement.

Here, a sort of mutual cooperation between the parties should be established.

On the other hand, it is the franchise agreement itself to build a kind of control from the franchiser over the franchisee, as the latter should run the business under the instructions of the franchiser, always bearing in mind that the franchisee is not an employee of the franchiser.

During the negotiations phase, the contract parties to be discuss on and determine the mutual rights and obligations to be fulfilled throughout the contract implementation. Their rights and duties start at this moment, given the characteristics of the franchise agreement. The franchise contract parties should disclose the state of the contract-related business affairs since the phase of negotiations. Specifically, they disclose information in terms of the franchise obligations' agenda. However, by attending such negotiations and exposing themselves to information of classified nature of substantial importance for the future of the business, the parties have the unavoidable obligation to keep the privacy of such information. Moreover, the law holds responsible the party, which, for intentional reasons, has failed to conclude the contract. 
Pursuant to article 1058 of the civil code, the party acting in good faith, which has attended the negotiations may claim compensation of costs incurred, should the contract fail to be concluded due to an intentional behavior of the other party. In this way, either the party failing to keep the privacy of information, or the party, which, intentionally and inconsistent with the principle of free market competition and good faith, as the most important principles characterizing the franchise agreement, attempts to get information just for starting up its own business without intending to sign the contract, are both held responsible. Article 1057 of the civil code provides the obligations of the franchiser. Precisely, "The franchiser should make available for the franchisee a number of standardized non-material rights, models, designs, profit, trade, organization ideas and other appropriate know-how to develop trade. So, this provision obviously sets forth the obligation of the franchisor to train the franchisee, so as the business of the latter be in compliance with the standards and reputation of the franchiser's business. "In the same way, the latter is due to preserve this agenda of obligations from breach of third parties, so as to constantly develop it and to support its implementation by the franchisee with instructions, information and improvements" (Law no. 7850, dated 29.07.1994 "Civil Code of the Republic of Albania" amended, article 1057).

Here it is highlighted the obligation of the franchiser to constantly provide, throughout the duration of the agreement, the franchisee with the necessary support so as the business of the latter be in compliance with the franchiser's standards.

On the other side, the Albanian legislation has not neglected a very important technical aspect in the content of this agreement.

It is about the protection of intellectual property rights related to the program granted by franchise. For breach of such rights by a third party either against the franchise business or against the franchiser, the latter has the obligation to protect such rights, thus emphasizing once again the personal characteristics or specifics that industrial property has.

However, even the franchisee is obliged to protect such rights in case of breach. This obligation originates from the combined interpretation to the civil code in relation to the Law on Industrial Property.

Precisely, article 1058 of the Civil Code provides that, while negotiating on the conclusion of the contract, the parties should disclose to each other the state of the commercial affairs related to the franchise agreement and specifically the agenda of the franchise obligations, and inform each other under the principles of good faith and legal safety. "The parties must not disclose classified information even if the contract is not concluded (Law no. 7850, dated 29.07.1994 "Civil Code of the Republic of Albania" amended, article 1058/1). The party breaching this obligation should compensate for the damage. Moreover, the second paragraph of this article provides even the deadline for the prescription of the right to sue for damage compensation arising from the breach of the obligation to not disclose (Law no. 7850, dated 29.07.1994 "Civil Code of the Republic of Albania" amended, article 1058/2). So, the focus is on a substantial element associated with the implementation of the franchise agreement, which is "privacy"

The essential characteristic of this agreement is the fact that rights and obligations on the parties do not extend only throughout the duration of the agreement, because article 1061 of the civil code sets forth even the provision of prohibition of unfair competition following the termination of the franchise agreement. In this way, the Albanian legislation intends to regulate the competition between the franchiser and the franchisee after the contract has terminated when referring to the classified information that the parties have shared throughout the implementation of the agreement (Law no. 7850, dated 29.07.1994 "Civil Code of the Republic of Albania" amended, article 1061/1)."Based on this, a prohibition of local competition for a period of up to one year may be imposed on the franchisee" (Law no. 7850, dated 29.07.1994 "Civil Code of the Republic of Albania" amended, article 1061/2). Should the prohibition of competition result in a decrease of its professional activity, an equitable financial compensation may be granted to the franchise notwithstanding the contract termination (Law no. 7850, dated 29.07.1994 "Civil Code of the Republic of Albania" amended, article 1061/3).

Referring to the principle of market freedom and fair competition, although the franchisee, following the contract termination, is not allowed to practice a similar business by used even the know-how obtained while implementing the franchise agreement, a reasonable compensation must 
be granted to the same in compliance with the legal term "equitable financial compensation" by the franchiser. In this way, the franchisee may indirectly take advantage of the know-how obtained, which is not through doing business using similar know-how and information to start up a similar business.

In addition to the rights and obligations of the franchiser, under the current Albanian legislation, even the franchisee has rights and obligations. The franchisee appears as the "investor" performing the business by using the trademark, brand name and know-how of the franchiser. The franchisee is obliged to follow the contract terms and above all to the relevant fee to the franchiser.

Under the law, it is on the franchiser to prove the existence of franchising rights and obligations "If there are no rights and obligations, or if the franchiser breaches other contract obligations, the franchisee has the right to reduce the payment of the relevant fee" (Law no. 7850, dated 29.07.1994 "Civil Code of the Republic of Albania" amended, article 1062).

So, in addition to the role that the franchiser plays in giving specifications on how the franchisee should do business, from an extended and systematic interpretation of the franchiser's rights and obligations, we see that the franchisee is obliged to strictly apply the know-how and instructions given by the franchiser on the business performance, so that there is a synchronization of standards. These information and rights supplied against payment by the franchiser to the franchisee make the bases of the relevant fee that the franchisee should pay to the franchiser. Should these rights reduce or suffer damage in a certain way, under article 1062, it is clearly determined that the amount to be reduced is decided by an impartial expert.

Furthermore, the law acknowledges to the franchisee the right to claim compensation for damage arising from contract breach by the franchiser (Law no. 7850, dated 29.07.1994 "Civil Code of the Republic of Albania" amended, article 1062/2). Such breaches may consist in the failure of the franchiser to provide constant information to the franchisee, as one of the most important element for a franchise agreement to exist.

On the other hand, it is the franchiser to claim compensation for damages should the agenda of the franchising obligations be insufficiently fulfilled or the contract terms be intentionally breached (Law no. 7850, dated 29.07.1994 "Civil Code of the Republic of Albania" amended, article 1063). Such terms consist in the regular payment of the relevant fee set forth in the franchise agreement by the franchisee in favor of the franchiser, the implementation of the franchising agenda including the conditions for business start up and contract development, and constant compliance with the franchise standards and quality of the franchiser's trademark or brand name. If the franchisee fails to successfully apply such terms, the civil code provides that the situation is a breach of the contract, and in this way, the franchiser, as the direct or indirect injured party, is entitled to claim compensation for damages by the franchisee.

An important element of the franchisee agreement is the compensation, which the Albanian legislation does not expressively consider one of the main obligations of the franchisee. However, referring to article 1062 of the civil code, and specifically to the second paragraph thereof, we see that the compensation is one of the obligations due on the franchisee: "“If there are no rights, or if the franchiser breaches other contract obligations, the franchisee has the right to claim compensation" (Law no. 7850, dated 29.07.1994 "Civil Code of the Republic of Albania" amended, article 1063). Moreover, the Albanian legislation neither sets forth any provision in terms of what compensation the franchisee should pay to the franchiser, nor if there will be any initial compensation followed by periodic payments under the contract terms or any other compensation method. Being franchising a relatively new type of agreement for the Albanian economic reality, it has not been yet regulated in detail so as to avoid problems in terms of rights and obligations of the contract parties. The Albanian legislation is somewhat ambiguous as far as the obligations of the franchiser and the franchisee are concerned, and in this aspect, it is necessary to intervene for the easy implementation of this agreement without creating conflicts due to the legal vacuum.

\subsection{Duration of the franchise agreement}

The duration of the franchise agreement is an important element of this contract. The duration is mainly related to the pursuance of long-term or short-term economic policies by the parties. It is 
directly related to the capital that the franchisee is going to invest and to its human resources. The experience of the franchisor is also important.

Practically, these contracts are made for a relatively short term with the right of constant contract renewal. However, the duration of the first franchise agreement must be sufficient for the franchisee to carry out the initial investment and obtain a fair and appropriate profit from the investment.

The franchiser is mostly interested in a longer duration of the contract for the benefits in terms of its business network extension and delivery of its trademark and brand name.

So, based on the duration of the contract, the franchiser has to adapt its policies to the franchisee's, so as the first may be well-recognized in the market and have an optimal service quality.

The franchise agreement may be entered into even for the duration that the parties deem reasonable "The duration of the contract is settled by the parties in compliance with the requirements dictated by the trade and relevant services" (Law no. 7850, dated 29.07.1994 "Civil Code of the Republic of Albania" amended, article 1061/1).

In this way, priority is given to the franchising service or good supplied and to the interests of both parties in favor of business extension, which is part of the service network supplied through franchising by the franchiser.

Contract duration is also related to the market requirements as well as to the interests of the parties in compliance with the service supplied, by always following the standards and the reputation of the franchiser.

The Albanian law provides a solution should the parties fail to expressively set forth a deadline for their agreement "If the contract contains no deadline, or if the deadline exceeds ten years, either party is entitled to waive the contract through one-year notice to the other party" (Law no. 7850, dated 29.07.1994 "Civil Code of the Republic of Albania" amended, article 1060/2).

Accordingly, given that the franchise agreement is made for a relatively short term, the party wishing to waive the contract, although no deadline has been provided therein, may only give a one-year notice to the franchiser.

The provision of the one-year term as a premise to waive the contract gives sufficient time to the franchiser to find another interested entity to continue the business under the brand name or trademark of the franchiser, whose reputation is already built.

Moreover, the one-year compulsory term to be followed by the franchiser serves the franchisee to reconsider its trade policies by employing another method or other goods or services through franchising, which the same franchisee will have one year to find.

In this case, the parties may foresee the duration for the application of the franchise agreement.

For cases when there is no term provided, the law obliges the waiving party to follow the oneyear notice term, with the aim of avoiding detrimental commercial tactics between the parties, even for cases when the term has been willfully missed in the contract.

The civil code provides no specific regulation with regard to contract renewal terms, and such a choice is left to the intention of the parties, which, in case of contract termination for expiry of the deadline or waiver, make efforts to agree on contract renewal, either under the same or different terms. Such effort should be made prior to the actual presentation of the works report, always following the principle of good faith "In case of contract termination for expiry of the deadline or waiver, and prior to actual presentation of the works report, the parties, guided by the principle of good faith, shall make efforts to agree on the contract renewal under the same or different terms" (Law no. 7850, dated 29.07.1994 "Civil Code of the Republic of Albania" amended, article 1060/2).

\subsection{Termination of franchise agreement}

Paragraph 2 or article 1060 of the civil code provides "If the contract contains no deadline, or if the deadline exceeds ten years, either party is entitled to waive the contract through one-year notice to the other party" (Law no. 7850, dated 29.07.1994 "Civil Code of the Republic of Albania" amended, article 1060/2). However, the law provides another case of contract termination other than the 
abovementioned deadline, which consists in the breach of those contract obligations, which seriously imperil the trade purpose. In such case, the contract party is entitled to waive the contract without reference to the deadline. However, although the law emphasizes the importance of the breach of contract obligations, which must be as serious as to imperil the trade purpose, the legal provision for such breaches is still ambiguous.

Therefore, referring to an extended interpretation of the abovementioned provision, the following actions or omissions will be considered as effective breaches:

1. Detriment of reputation, brand name or trademark of the good or service granted in franchising

2. Flow of classified information, which seriously harm the business;

3. Actions or omissions that would harm the relation between the parties, which is essential for the continuity of the franchise agreement, such as misuse of intellectual property; mental disability of the parties; failure to achieve necessary publicity; or failure of the franchiser to make available the system of rights, etc.

The Albanian law sets forth no provision on which party may be entitled to such right, thus enabling either the franchiser or the franchisee to terminate the contract once the breach of contract obligations imperils the trade purpose.

On the other side, the law provides no right of the franchiser to terminate the contract, in case the same franchiser, throughout the training period, finds that the franchisee is not the appropriate entity to fulfill the franchising obligations agenda. The provision of such case would give more guarantees to the franchiser and would reduce the risks of the latter under the franchise agreement, whereas, the lack of such provision goes in favor of the franchisee.

Referring to an extended interpretation of the Albanian legislation in terms of the franchise agreement, we conclude that it may terminate in the following cases:

a. Upon expiry of the deadline for which the contract has been concluded between the franchiser and franchisee, although the parties may attempt in the future to enter into a new contract. In such case, there is no possibility to renew the contract, as the latter has expired. If the parties wished to renew the contract, they must have done it prior to the expiry of the deadline and prior to the presentation of the actual works' report. Therefore, the only alternative is to enter into a new contract either with the same or different terms.

b. Upon waiver of contract by either party following the one-year notice term, should the contract provide no deadline or should the deadline exceed 10 years.

c. Upon termination of the contract by settlement between the parties, once their interests or goals to enter into the contract are inconsistent with their mutual economic interests or market conditions set forth at the moment of contract conclusion.

d. Upon termination of the contract by one party only, as in the case of the breach of contract obligations, which would seriously imperil the trade purpose. In this case there is no need to follow the deadline, because the breaches are serious, and if the breaching party kept doing business in that way, the profit would substantially fall.

\section{Conclusions}

The franchise is a relatively new agreement in terms of its use in Albania, although it has been existing for a long time.

The Albanian legislation regulates the franchise agreement under its Chapter XX, Title 2, Part $V$ of the Civil Code of the Republic of Albania, from article 1056 to article 1064 - a small space of 9 provisions.

Given the current business developments, the space dedicated to the franchise agreement, although a novelty for the time when the Albanian civil code became effective is not fully consistent with the market requirements.

Specifically, the provisions of the civil code generally set forth some pre-contract phases, in which the parties are in unfavorable positions. Such pre-contract phase includes the supply of information from the franchiser to the franchisee, as well as the weakness of the franchisee in comparison with the franchiser, as the latter has the power to choose the appropriate franchisee to 
expand the business. At his point, the civil code needs to be amended, as no provision is set forth on the fundamental right of the franchiser to interrupt the negotiations with the franchisee, should the latter be an inappropriate individual to start a business using the brand name, trademark and reputation of the franchiser. In this aspect, the franchiser should have more rights, given that under the current rights laid out in the Albanian civil code, the same is not safe to get involved in a franchise agreement.

As to the form of the franchise agreement, the Albanian civil code provides that it should be in written to the effect of verifiability rather than validity. This results from the interpretation of the provisions, as it is not expressively determined.

Another shortcoming of the Albanian civil code is that it says nothing on the sub-franchising. However, in such a situation the case-law would be needed to decide in that regard. But, when the reality obviously reflects a massive non-recognition of such agreement, even the case-law is almost inexistent in terms of such issue. However, based on the case-law of foreign countries and under the interpretation of the principles of the legal-civil relation, as well as an extended and systematic interpretation of the civil code provisions, we conclude that the sub-franchising agreement may be applied with the consent of the franchiser. Anyway, this is not an issue to be resolved only through the extended interpretation of the provisions on the franchise agreement or relevant jurisprudence thereof.

The Albanian civil code should include this provision so as to avoid any eventual confusion in case the parties wished to enter into a sub-franchising agreement. In regulating this issue, it would be worth taking the example of the Australian legislation in terms of sub-franchising, as it clearly sets forth when this type of agreement is allowed and the obligation of the franchiser to not impede its entering into without justified reasons.

Another shortcoming of the Albanian civil code relates to the treatment of rights and obligations of the parties under a franchise agreement, except for the guarantee it provides to the parties in case of contract non-conclusion, by obliging them to not disclose classified information exchanged during the negotiation phase.

With regard to the method of fee payment by the franchisee to the franchiser, there is not provision set forth in our civil code, and this make the parties address to a consensual solution.

If we refer to the international legislation, it lays out how essential it is to define the way the payment has to be made by the franchisee to the franchiser, if it will be periodic or if there will by any initial payment in addition to the usual one.

If the aim was to promote this contract so at is widely used in the domestic economy, the rights and obligations of the parties should have been more specific and detailed. It would have guaranteed their position with more safety and information on the liberality and flexibility this contract offers, in a way that differs from the other contracts of doing business.

In the framework of the integration to the EU, Albanian should refer to the legislation of the European Union, as well as to the international legislation in general, given that they are will completed in terms of the franchise agreement, and specifically in terms of the protection of rights and obligations of the parties.

In conclusion, we should note that franchising, notwithstanding its complexity, has a considerable potential in the economic development of a country. The promotion of the franchising method of doing business would facilitate the economic development in Albania and would increase social welfare.

So, in this aspect, this legal-civil relation deserves more legal space and treatment, being a new although extremely efficient instrument in developing a modern society.

Its implementation would also develop the doctrine and jurisprudence, in terms of theory and practice respectively, which means giving a clearer and more accurate picture of this type of agreement.

\section{References}

Law no. 7850, dated 29.07.1994 'Civil Code of the Republic of Albania', amended

Law no. 9901, dated 14.04.2008 'Traders and trade companies', amended 
Academy of Sciences of Albania, Institute of Language and Literature. Vocabulary of Modern Albanian, Tirana: Toena, 2002

B. Murphy, Kevin. The Franchise Handbook: A Complete Guide to all Aspects of Buying, Selling or Investing in a Franchise, USA: Atlanta Publishing Group, Inc., 2006.

Brandon, Ruth. Capitalist Romance, Philadelphia: Lippincott, 1977.

Gamet-Pol Francoise, J. Franchise Agreements within The European Community, USA: Transnational Publishers, Inc.1997.

Gurnick. David, Distribution Law of the United States, U.S.: Juris Publishing, 2011.

The European Court of Justice , 28.01.1986, case no.161/84.

Lafontaine, Francine; H. Rubin. Pul, Franchise Contracting and Organization, Cheltenham: Elgar, 2005.

Lapowsky, Issie Inc. (magazine): How to Start a Home-Based Franchise, New York: Mansueto Ventures, 13.05.2010.

Mendelsohn, Martin. The guide to franchising, 7th edition, London: Thomson, 2005.

Murray, lain. How to choose a franchise, UK: Express Newspapers, 2004.

Oxford English Dictionary, Great Britain: Oxford University Press, 1933.

Peters Lena \& Schneider Marina, 'The Franchising Contract, Preliminary Study', Unidroit: Romë, Tetor, 1986.

Rogers Cooper, Grace. History of the Sewing Machine, Washington: The Smithsonian Institution Press, 2004.

Thomas S. Dicke, Franchising in America: The Development of a Business Method, 1840-1980, North Carolina: The University of North Carolina Press, 2010. 